\title{
CONCURRENT VALIDITY OF INSTRUMENTS FOR MEASURING SPEED OF MOVEMENT IN LEG PRESS EXERCISES
}

\author{
VALIDADE CONCORRENTE DE INSTRUMENTOS PARA MEDIRA VELOCIDADE DE MOVIMENTO EM \\ EXERCIOOS DELEG PRESS
}

Original Articie

ARTIGO ORIGINAL Artículo Original

\section{VALIDEZ CONCURRENTE DE LOS INSTRUMENTOS PARA MEDIR LA VELOCIDAD DE MOVIMIENTO ENLOS EXERCICIO DELEG PRESS}

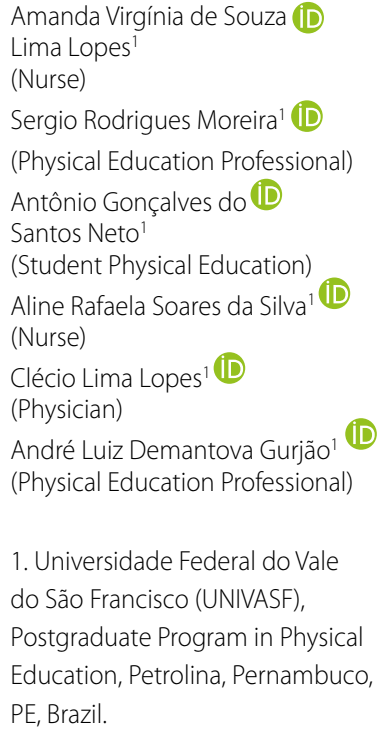

\section{Correspondence:}

André Luiz Demantova Gurjão. Universidade Federal do Vale do São Francisco (UNIVASF), Colegiado de Educação Física (CEFIS). Av. José de Sá Maniçoba, $\mathrm{S} / \mathrm{N}$, Centro, Petrolina, PE, Brazil. 56304-917.

andre.gurjao@univasf.edu.br

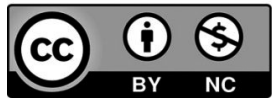

\begin{abstract}
Introduction: Adequate measurement of movement velocity in strength exercises can assist in the prescription and evaluation of training effects. Objective: The objectives of the present study were to analyze the reliability (test-retest) and concurrent validity of the movement velocity measured by means of the electrogoniometer and accelerometer during horizontal leg press exercise at different intensities $(40,60,80 \%$ of a maximum repetition - 1RM). Methods: Eighteen young women attended the laboratory on five occasions. After determining the maximum dynamic force, two visits (separated by 48-72 hours) were used to verify the reliability (test-retest) for different speed variables in the three intensities. Results: The mean propulsive velocity obtained by the goniometer showed higher Intraclass correlation coefficients (ICC) and lower coefficients of variation compared to the accelerometer. The same behavior was observed for both the mean velocity and the peak velocity. The propulsive time was more reproducible and with less variation for the accelerometer and bad CCl for both sensors were observed at $60 \%$ of $1 \mathrm{RM}$. When the sensors are compared, the mean and average propulsive velocities presented moderate ratios with a large to very large standardized medium bias. Conclusion: The potentiometer of the electrogoniometer can be used to estimate the velocity in the horizontal leg press exercise, especially for loads of 60 and $80 \%$. The performance of the accelerometer was inferior to that of the potentiometer. Level of evidence Il; Diagnostic studies.
\end{abstract}

Keywords: Resistance training; Performance; Kinematics.

\section{RESUMO}

Introdução: A adequada mensuração da velocidade de movimento nos exercícios de força muscular pode auxiliar na prescrição e avaliação dos efeitos do treinamento. Objetivo: Os objetivos do presente estudo foram analisar a confiabilidade (teste-reteste) e validade concorrente da velocidade de movimento mensurada por meio do eletrogoniômetro e acelerômetro durante exercício leg press horizontal em diferentes intensidades (40,60, 80\% de uma repetição máxima - 1RM). Métodos: Dezoito mulheres jovens compareceram ao laboratório em cinco ocasiões. Após determinação da força dinâmica máxima, duas visitas (separadas por 48-72 horas) foram destinadas a verificação da confiabilidade (teste-reteste) para diferentes variáveis de velocidade nas três intensidades. Resultados: A velocidade média propulsiva obtida pelo goniômetro apresentou maiores coeficientes de correlação Intraclasse (CCI) e menores coeficientes de variação em comparação ao acelerômetro. O mesmo comportamento foi verificado tanto para a velocidade média quanto a pico. O tempo propulsivo foi mais reprodutível e com menor variação para o acelerômetro e CCI ruins para ambos os sensores foram observados em 60\% de 1RM. Quando os sensores são comparados, a velocidade média e média propulsiva apresentaram relações moderadas com viés médio padronizado grande a muito grande. Conclusão: O potenciômetro do eletrogoniômetro pode ser utilizado para estimar a velocidade no exercício leg press horizontal, em especial, para cargas de 60 e 80\%. O desempenho do acelerômetro se mostrou inferior ao do potenciômetro. Nível de evidência ll; Estudos diagnósticos.

Descritores: Treinamento de resistência; Desempenho; Cinemática.

\section{RESUMEN}

Introducción: La medición adecuada de la velocidad de movimiento en los ejercicios de fuerza muscular puede ayudar en la prescripción y evaluación de los efectos del entrenamiento. Objetivo: Los objetivos del presente estudio fueron analizar la confiabilidad (test-retest) y la validez concurrente de la velocidad de movimiento medida por medio del electrogoniómetro y acelerómetro durante ejercicio leg press horizontal en diferentes intensidades $(40,60,80 \%$ de una repetición máxima - 1RM). Métodos: Dieciocho mujeres jóvenes asistieron al laboratorio en cinco ocasiones. Después de la determinación de la fuerza dinámica máxima, dos visitas (separadas por 48-72 horas) fueron destinadas a verificación de la confiabilidad (test-reteste) para diferentes variables de velocidad en las tres intensidades. Resultados: La velocidad media propulsiva obtenida por el goniómetro presentó mayores coeficientes de correlación Intraclasse (CCl) y menores coeficientes de variación en comparación al acelerómetro. El mismo comportamiento se verificó tanto para la velocidad media como la pico. El tiempo propulsivo fue más reproducibley con menor variación para el 
acelerómetro y CCI malos para ambos sensores se observó en un 60\% de 1RM. Cuando los sensores son comparados, la velocidad media y media propulsiva presentaron relaciones moderadas con sesgo medio estandarizado grande a muy grande. Conclusión: El potenciómetro del electrogoniómetro puede ser utilizado para estimar la velocidad en el ejercicio leg press horizontal, en especial, para cargas de 60 y $80 \%$. El rendimiento del acelerómetro se mostró inferior al del potenciómetro. Nivel de evidencia Il; Estudios dianósticos.

Descriptores: Entrenamiento resistência; Rendimiento; Cinemática.

\section{INTRODUCTION}

Resistance training programs have been recommended to promote positive changes in different variables related to health and athletic performance. The control of training variables plays a key role in the acute responses of the neuromuscular system and, consequently, in the chronic adaptations to training. ' The manipulation of the movement velocity results in different neural, morphological and metabolic responses to resistance exercise and has been shown to be useful when the objective is to alter the training stimulus. ${ }^{2-4}$ In addition, the analysis of movement velocity behavior during isoinertial laboratory evaluation allows the individual to explore the relationship between movement velocity and load (i.e., different percentages of a maximal repetition), to discriminate individuals with different levels of performance, besides being an indicator of neuromuscular fatigue when analyzed in series performed until concentric muscular failure. ${ }^{2,5-7}$ In this context, measuring and analyzing the movement velocity in laboratory conditions and during training routines has great relevance for exercise professionals and practitioners.

Studies investigating the relationship between load and movement velocity in different exercises or within variations of the same exercise found significant differences in the velocity parameters analyzed. ${ }^{8,9}$ Conceição et al., ${ }^{8}$ for example, found that the relation between load and maximum concentric velocity are similar for full squat and half squat, but different for leg press $45^{\circ}$. When the relationship between load and mean propulsive velocity was analyzed, the three exercises differed from each other. García-Ramos et al. ${ }^{9}$ observed that the mean concentric velocity associated with different percentages of maximal strength was significantly higher when the supine exercise was performed in the eccentric-concentric technique compared to the only concentric technique. Collectively, these results indicate that the load-velocity relationship may depend on both the velocity parameter analyzed and the exercise or technique used. The leg press is an exercise in great popularity and the equipment may have varied configurations (e.g., horizontal or $45^{\circ}$ ). The leg press $45^{\circ}$ has a movable weight platform moved by the practitioner. On the other hand, the horizontal leg press has a fixed platform and a movable seat connected to a tower of weights by cables and pulleys that moves along with the body of the practitioner. Because the relationship between load and velocity is dependent on the exercise and the kinematic parameters analyzed, it remains to establish the equations that describe this relationship in the horizontal leg press exercise and its reliability.

Due to the importance of measuring the movement velocity, different technologies based on linear position transducers (LPT), accelerometers or inertial systems (accelerometers associated with gyroscopes) have been developed to determine the movement velocity in resistance exercises. ${ }^{10-12}$ Among the different LPT models, there are those that can be connected to resistive exercise equipment by means of cables and record electrical signals proportional to the displacement performed. In this case, the VM is obtained by differentiating the displacement in the corresponding time. On the other hand, capacitive accelerometers are based on the principle of capacitance change in response to acceleration applied in a seismic mass and the VM is obtained by means of the cumulative sum of the acceleration integral in time. Previous studies performed in the bench press and squat exercises showed that both technologies are valid to determine the movement velocity when comparing video or other laboratory equipment. ${ }^{10,13-16}$

Although the different technologies used to measure the VM can allow a more accurate control of resistance training programs, the cost of acquisition and the need for technical adaptations to synchronize information from these technologies with signals from other systems (e.g, force platform and electromyography) can make it difficult or unfeasible to use. ${ }^{15}$

An alternative to the TLP that use cables is the fixation of an electrogoniometer to the dynamometer. Electrogoniometers are capacitive linear transducers connected to rods of fixed length that record electrical signals proportional to the change of angle between the rods. Using trigonometric concepts it is possible to determine the displacement between two parts of the dynamometer connected to the rods of the electrogoniometer and, thus, to deduce the movement velocity through the differentiation. The electrogoniometers have the advantage of being commonly found as part of signal acquisition systems in laboratory environments. Another advantage is that the acquisition systems synchronously register signals from other sensors such as dynamometry, electromyography and accelerometry. However, it remains to be established whether the electrogoniometer and accelerometer can be adapted to the horizontal leg press and provide measurements with adequate reliability of the movement velocity. The purpose of the present study was to analyze the reliability of the measured VM through the electrogoniometer and accelerometer during horizontal leg press exercise performed at different intensities and to compare the measurements among the sensors.

\section{METHODS \\ Participants}

Participating in the study were 18 university-age women practicing physical activities ( $\geq 2 x$ per week) (age: $24.2 \pm 3.8$ years, height: $1.60 \pm$ $0.06 \mathrm{~m}$, body mass: $55.1 \pm 6.1 \mathrm{~kg}$, body mass index: $22.7 \pm 4.7 \mathrm{~kg} / \mathrm{m}^{2}$ ). All participants were informed of the procedures to be adopted and aimed at signing the Informed Consent Term (Resolution of 466/12 of the National Health Council). The number of the Certificate of Presentation for Ethical Appreciation (CPAE) was: 79487517.3.0000.5196.

Participants visited the laboratory on five different occasions. The three initial visits (48 hours apart) were used to determine the maximum dynamic force (One repetition maximum testing - 1RM) and to familiarize the maximum velocity movement technique. The two subsequent visits (separated by 48-72 hours) were used to verify the reliability (test-retest) for different velocity variables at three intensities (40,60 and $80 \%$ of 1RM) in the horizontal leg press exercise. The displacement of the equipment was simultaneously recorded by means of the linear transducer of the electrogoniometer and the accelerometer. All evaluations were performed at the same time to minimize possible circadian variations in the 
dependent variables. The participants were instructed not to engage in any intense physical activity during the study period and to avoid alcohol and caffeine intake within 24 hours prior to the evaluations.

\section{Instrumentation of horizontal leg press and signal analysis}

The horizontal leg press equipment (Cyber Tech, São José do Rio Preto, SP, Brazil) was chosen because it is a widely used exercise for the training and evaluation of lower limb neuromuscular performance. The equipment consists of a stationary platform (place of positioning of the feet of the subject) and a mobile seat connected to a tower of weights by means of steel cable and pulley. The signals of the electrogoniometer and accelerometer were synchronized by an A/D signal conditioning board (EMG System, São José dos Campos, SP, Brazil) with a sampling frequency of $2000 \mathrm{~Hz}$ and stored on hard disk (Lenovo iDeiaPad 320 notebook) for analysis off-line by means of specific algorithm. As a first procedure of the algorithm, all signals were filtered through a fourth-order Butterworth filter and cut-off frequencies determined based on signal-to-noise ratio residue analysis. All other procedures were performed on the filtered signals. The electrogoniometer was incorporated into the equipment to determine the beginning and end of the concentric phase of each repetition and to estimate the movement velocity. One of the rods of the electrogoniometer was fixed at one stationary point at the end of the slide rail of the seat and the other rod in the movable seat itself, both aligned with the longitudinal axis of the displacement forming a triangle. When considering that the linear potentiometer of the electrogoniometer measures the changes of angles between its rods, whose sizes are known, the law of cosines was used to determine the displacement of the mobile seat and, subsequently, to generate the absolute velocity curves. The accuracy of the linear potentiometer of the electrogoniometer in measuring seat displacement was $2 \mathrm{~mm}$ or $0.4^{\circ}(r=0.97$, standard error of estimation = $0.65 \mathrm{~mm}$, mean standardized bias trivial $=0.01$ ). The accelerometer was fixed to the weight tower with the purpose of subdividing the concentric phase into the propulsive stage (acceleration $>0$ ), braking (acceleration <0) and generating the absolute velocity curves (i.e., sum of the instantaneous velocities). The instantaneous velocities were determined as a numerical integration of the acceleration signal in the shortest possible time variation $(0.0005 \mathrm{~s}) .{ }^{16}$ Based on this information, the following variables were obtained on both sensors: mean propulsive velocity, mean concentric velocity, peak velocity and propulsive time.

\section{Maximum dynamic force (1RM)}

The sliding seat was individually adjusted for the knee angle to start the effort by $90^{\circ}\left(0^{\circ}=\right.$ extended knees $)$ and used during all procedures. The arms were positioned parallel to the trunk, with hands resting on the seat support. First a warming-up set was performed with 15 repetitions at $50 \%$ of the estimated load for the first attempt of each test day, followed by a set of six repetitions at 70\% (1 minute recovery interval). During warming-up, the execution technique was standardized (maximum velocity) and continuously monitored. After recovery time of 3 minutes the load was adjusted and participants were asked to perform two repetitions. Being successful, the load was increased by around 3 to $10 \%$. After a recovery interval of 3-5 minutes the second attempt was initiated. If one or two repetitions were performed, the load was increased again. In situations where the participant did not succeed in moving the load, reductions of 3 to $10 \%$ were made. On each test day a maximum of five attempts with verbal encouragement were made. The highest charge moved for one repetition was used for the analyzes.

\section{Reliability of the load-velocity relationships}

Each of the two visits consisted of a specific warming-up routine in the leg press (15 repetitions with 30\% of $1 \mathrm{RM}$ and maximum velocity).
After the 2-minute interval, the participants performed three continuous repetitions with the highest possible velocity of movement with 40,60 and $80 \%$ of 1RM (random order). Rest interval of 2 minutes was offered between intensities and verbal encouragement was offered during repetitions. The repetition with higher peak velocity was adopted for the analyzes.

\section{Statistical analysis}

All analyzes were performed separately for each relative intensity. Relative reliability was determined by the intra-class correlation coefficient (ICC). Absolute reliability was examined using the standard error of absolute measure (SEM) and relative coefficient of variation (SEM-CV - acceptable <15\%). Paired t-test was used to compare the mean values between test-retest. To compare the sensors, the following analyzes were used: Pearson correlation coefficient, standard error of estimation (absolute and coefficient of variation) and standardized mean bias. ${ }^{17}$ The level of significance was $5 \%$ and the confidence interval was 95\%.

\section{RESULTS}

The mean propulsive velocity obtained by the goniometer showed higher ICC and lower coefficients of variation (Table 1). The same behavior was observed for both the mean velocity and the peak velocity. The propulsive time was more reproducible and with less variation for the accelerometer and bad ICC for both sensors were observed at $60 \%$. Figure 1 shows the load-velocity relationships for both sensors in the two tests and allows to visualize the average changes between the tests, both for the average velocity and the propulsive average obtained by the goniometer (see differences indicated in Table 1). When the sensors are compared (Table 2), the mean and average propulsive velocities presented moderate relations with medium standardized bias from large to very large. Good to excellent ratios with a standardized trivial to small bias were observed for peak velocity and propulsive time.

\section{DISCUSSION}

The present study had as objectives to determine the test reliability test and to compare the estimates of the different velocity parameters obtained by the potentiometer of the electrogoniometer and the accelerometer. Lower reliability was observed for the accelerometer because it presented smaller CCl and greater variations for most velocity analyzed in the different percentages of load. (Table 1) The comparison between the sensors indicated that they can not be used interchangeably when the objective is to analyze the mean and average propulsive velocities, as indicated by the moderate correlation coefficients and the large to very large standard biases.

Other studies have reported systematic biases by comparing velocities obtained by accelerometers and other sensors during resistance exercises, with lower mean velocity values and less reproducibility presented by accelerometers. ${ }^{12,16,18,19}$ Different factors may be related to this behavior, such as errors related to acquisition of acceleration and / or signal processing. In some situations the participants of this study had enabled impacts the end of the eccentric phase. As accelerometers were not designed to absorb impacts, this condition interfered with the acceleration reading, especially at the beginning of the concentric phase. Further analysis of the raw data showed that after the impacts, the oscillation generated on the accelerometer signal led the algorithm to start instantaneous velocity calculations with negative acceleration. As a consequence, velocity values were underestimated during the cumulative summation. Thus, caution is required in interpreting the load-velocity relationships obtained by the accelerometer. 
Table 1. Mean values, standard deviations and results from relative and absolute reliability for mean propulsive velocity, mean velocity, peak velocity and propulsive duration $(n=18)$.

\begin{tabular}{|c|c|c|c|}
\hline & $40 \%$ & $60 \%$ & $80 \%$ \\
\hline \multicolumn{4}{|l|}{$\begin{array}{l}\text { Mean propulsive } \\
\text { velocity }\left(\mathrm{m} \cdot \mathrm{s}^{-1}\right)\end{array}$} \\
\hline Goniometer T1 & $0.529 \pm 0.08$ & $0.443 \pm 0.05$ & $0.326 \pm 0.04$ \\
\hline Goniometer T2 & $0.574 \pm 0.08^{*}$ & $0.480 \pm 0.07^{*}$ & $0.361 \pm 0.05^{*}$ \\
\hline ICC & 0.72 & 0.75 & 0.77 \\
\hline $\operatorname{SEM}\left(m \cdot s^{-1}\right)$ & 0.05 & 0.03 & 0.02 \\
\hline SEM-CV (\%) & 8.2 & 6.8 & 7.3 \\
\hline Accelerometer T1 & $0.409 \pm 0.08$ & $0.327 \pm 0.06$ & $0.224 \pm 0.08$ \\
\hline Accelerometer T2 & $0.418 \pm 0.09$ & $0.344 \pm 0.06$ & $0.246 \pm 0.05$ \\
\hline ICC & 0.74 & 0.66 & 0.58 \\
\hline $\operatorname{SEM}\left(m \cdot s^{-1}\right)$ & 0.04 & 0.04 & 0.04 \\
\hline SEM-CV (\%) & 9.9 & 10.9 & 18.2 \\
\hline \multicolumn{4}{|c|}{ Mean velocity $\left(\mathrm{m} . \mathrm{s}^{-1}\right)$} \\
\hline Goniometer T1 & $0.513 \pm 0.07$ & $0.442 \pm 0.05$ & $0.340 \pm 0.05$ \\
\hline Goniometer T2 & $0.549 \pm 0.07^{*}$ & $0.471 \pm 0.06^{*}$ & $0.369 \pm 0.05^{*}$ \\
\hline ICC & 0.68 & 0.77 & 0.90 \\
\hline $\operatorname{SEM}\left(m \cdot s^{-1}\right)$ & 0.04 & 0.03 & 0.02 \\
\hline SEM-CV (\%) & 7.4 & 6.2 & 4.4 \\
\hline Accelerometer T1 & $0.393 \pm 0.08$ & $0.333 \pm 0.07$ & $0.266 \pm 0.06$ \\
\hline Accelerometer T2 & $0.389 \pm 0.10$ & $0.345 \pm 0.07$ & $0.264 \pm 0.05$ \\
\hline ICC & 0.68 & 0.57 & 0.77 \\
\hline $\operatorname{SEM}\left(m \cdot s^{-1}\right)$ & 0.05 & 0.05 & 0.03 \\
\hline SEM-CV (\%) & 12.3 & 13.7 & 9.9 \\
\hline \multicolumn{4}{|l|}{ Peak Velocity $\left(\mathrm{m} . \mathrm{s}^{-1}\right)$} \\
\hline Goniometer T1 & $0.740 \pm 0.09$ & $0.646 \pm 0.08$ & $0.513 \pm 0.08$ \\
\hline Goniometer T2 & $0.779 \pm 0.10$ & $0.670 \pm 0.10$ & $0.537 \pm 0.08^{*}$ \\
\hline ICC & 0.70 & 0.74 & 0.91 \\
\hline $\operatorname{SEM}\left(m \cdot s^{-1}\right)$ & 0.05 & 0.05 & 0.02 \\
\hline SEM-CV (\%) & 7.1 & 7.0 & 4.7 \\
\hline Accelerometer T1 & $0.700 \pm 0.14$ & $0.607 \pm 0.12$ & $0.501 \pm 0.11$ \\
\hline Accelerometer T2 & $0.724 \pm 0.16$ & $0.645 \pm 0.13$ & $0.519 \pm 0.11$ \\
\hline ICC & 0.70 & 0.64 & 0.82 \\
\hline $\operatorname{SEM}\left(m \cdot s^{-1}\right)$ & 0.08 & 0.08 & 0.05 \\
\hline SEM-CV (\%) & 11.3 & 12.2 & 9.4 \\
\hline \multicolumn{4}{|c|}{ Propulsive duration (s) } \\
\hline Goniometer T1 & $0.227 \pm 0.05$ & $0.283 \pm 0.05$ & $0.383 \pm 0.09$ \\
\hline Goniometer T2 & $0.198 \pm 0.04^{*}$ & $0.253 \pm 0.05^{*}$ & $0.333 \pm 0.07^{*}$ \\
\hline ICC & 0.66 & 0.37 & 0.61 \\
\hline $\operatorname{SEM}\left(m \cdot s^{-1}\right)$ & 0.03 & 0.04 & 0.05 \\
\hline SEM-CV (\%) & 12.9 & 15.5 & 14.5 \\
\hline Accelerometer T1 & $0.241 \pm 0.04$ & $0.304 \pm 0.04$ & $0.422 \pm 0.08$ \\
\hline Accelerometer T2 & $0.225 \pm 0.04^{*}$ & $0.279 \pm 0.05^{*}$ & $0.371 \pm 0.06^{*}$ \\
\hline ICC & 0.74 & 0.48 & 0.72 \\
\hline $\operatorname{SEM}\left(m \cdot s^{-1}\right)$ & 0.02 & 0.03 & 0.04 \\
\hline SEM-CV (\%) & 8.5 & 11.3 & 9.9 \\
\hline
\end{tabular}

$\mathrm{T} 1=$ Test $1 ; \mathrm{T} 2=$ Test 2 (retest); $\mathrm{ICC}=$ Intraclass correlation coefficient; $\mathrm{SEM}=$ Standard error of the measurement $\mathrm{SEM}-\mathrm{CV}=$ Standard error of the measurement as coefficient of variation; ${ }^{*}=$ significant difference in relation to T1.
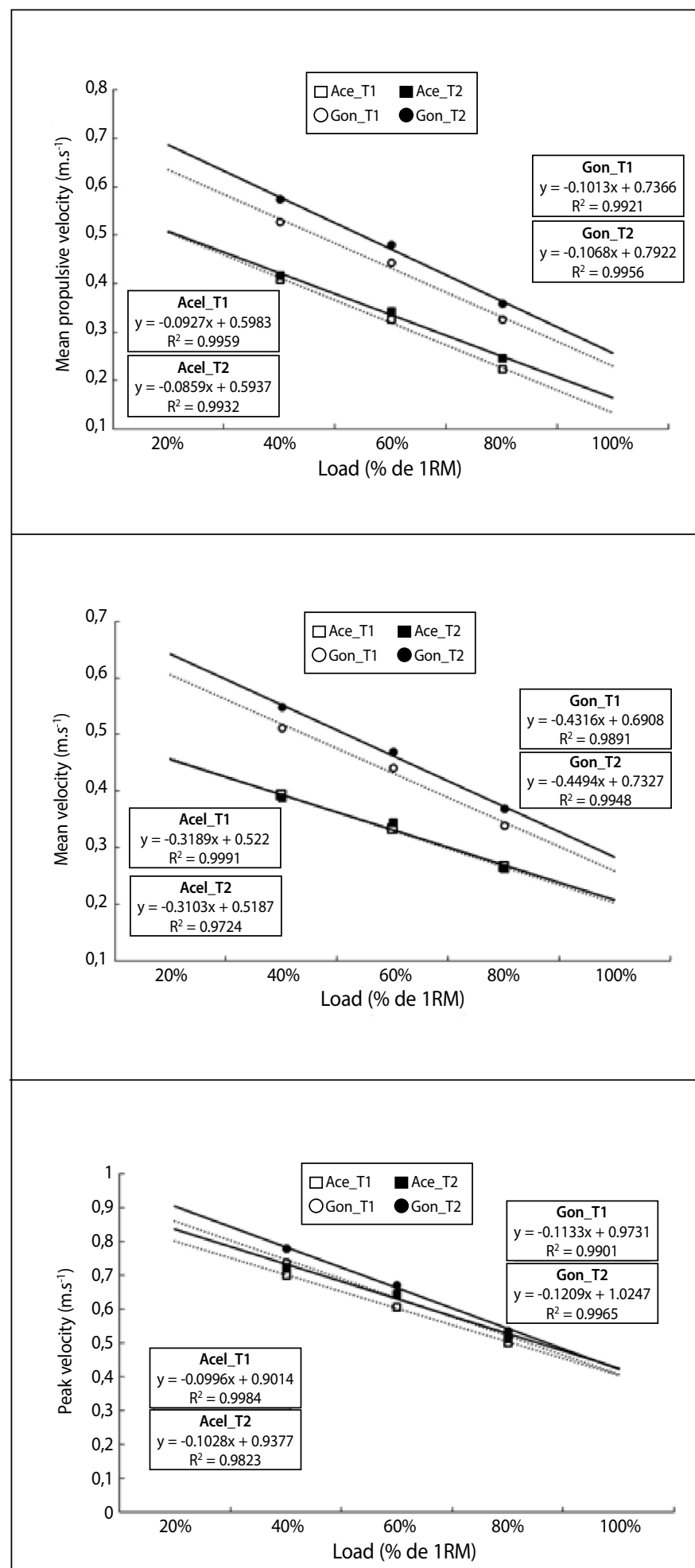

Figure 1. Load-velocity relationship for different velocity parameters (mean values; $n=18$ ) obtained by the goniometer (Gon) and accelerometer (Acel) in the test (T1) and retest (T2).

The mean velocities and propulsive means obtained by the potentiometer presented higher values in the retest. Due to the lower variability in the measurements of the potentiometer, it is possible that this fact may be related to the familiarization of the participants to the exercise performed. In addition, García-Ramos et al. ${ }^{9}$ show that the CCls obtained in test-retest can vary depending on the intensity of the exercise. Similar to these findings, in the present investigation larger $\mathrm{CCls}$ were observed for intensity of 60 and $80 \%$ of 1 RM when the velocity is obtained by the potentiometer. 
Table 2. Concurrent validity between accelerometer and goniometer for estimates of mean propulsive velocity, mean velocity, peak velocity and propulsive duration at different intensities. The data are presented in values and confidence interval of 95\%.

\begin{tabular}{|c|c|c|c|}
\hline & $40 \%$ & $60 \%$ & $80 \%$ \\
\hline \multicolumn{4}{|c|}{ Mean propulsive velocity } \\
\hline SEE-CV (\%) & 14.9 (10.7 a 24.5) & $7.3(5.3$ a 11.8$)$ & $16.0(11.5$ a 26.4$)$ \\
\hline $\mathrm{MB}\left(\mathrm{m} \cdot \mathrm{s}^{-1}\right)$ & $-0.12(-0.16 a-0.08)$ & $-0.12(-0.14$ a -0.09$)$ & $-0.10(-0.14$ a -0.07$)$ \\
\hline $\operatorname{MBS}\left(m \cdot s^{-1}\right)$ & $-1.42(-1.88$ a -0.96$)$ & $-2.40(-2.84$ a -1.95$)$ & $-2.28(-3.08$ a -1.48$)$ \\
\hline \multicolumn{4}{|l|}{$\begin{array}{c}\text { Mean } \\
\text { Velocity }\end{array}$} \\
\hline SEE-CV (\%) & $12.3(8.9$ a 20.1$)$ & $7.6(5.5$ a 12.3$)$ & $10.6(7.7$ a 17.3$)$ \\
\hline $\operatorname{SEE}\left(m \cdot s^{-1}\right)$ & $0.06(0.04$ a 0.09$)$ & $0.03(0.02$ a 0.05$)$ & $0.03(0.02$ a 0.05$)$ \\
\hline $\mathrm{MB}\left(\mathrm{m} \cdot \mathrm{s}^{-1}\right)$ & $-0.12(-0.16$ a -0.08$)$ & $-0.11(-0.13$ a -0.09$)$ & $-0.07(-0.10 \mathrm{a}-0.05)$ \\
\hline $\operatorname{MBS}\left(m \cdot s^{-1}\right)$ & $-1.81(-2.37 \mathrm{a}-1.25)$ & $-2.13(-2.59 a-1.66)$ & $-1.62(-2.10 a-1.13)$ \\
\hline \multicolumn{4}{|l|}{$\begin{array}{c}\text { Peak } \\
\text { Velocity }\end{array}$} \\
\hline $\operatorname{MBS}\left(m \cdot s^{-1}\right)$ & $-0.43(-0.91$ a 0.06$)$ & $-0.49(-0.96 a-0.02)$ & $-0.15(-0.54$ a 0.23$)$ \\
\hline \multicolumn{4}{|l|}{$\begin{array}{l}\text { Propulsive } \\
\text { Duration }\end{array}$} \\
\hline Pearson (r) & $0.82(0.55$ a 0.94$)$ & $0.83(0.56$ a 0.94$)$ & $0.95(0.86$ a 0.98$)$ \\
\hline SEE-CV (\%) & $14.2(10.2$ a 23.4$)$ & 12.4 (9.0 a 20.3) & $7.6(5.5$ a 12.3$)$ \\
\hline $\operatorname{SEE}\left(m \cdot s^{-1}\right)$ & $0.03(0.02$ a 0.04$)$ & $0.03(0.02$ a 0.05$)$ & $0.03(0.02$ a 0.04$)$ \\
\hline $\mathrm{MB}\left(\mathrm{m} \cdot \mathrm{s}^{-1}\right)$ & 0.01 (0.00 a 0.03$)$ & $0.02(0.01$ a 0.04$)$ & $0.04(0.02$ a 0.05$)$ \\
\hline $\operatorname{MBS}\left(m \cdot s^{-1}\right)$ & 0.31 (0.01 a 0.61$)$ & $0.40(0.10$ a 0.70$)$ & $0.44(0.27$ a 0.60$)$ \\
\hline
\end{tabular}

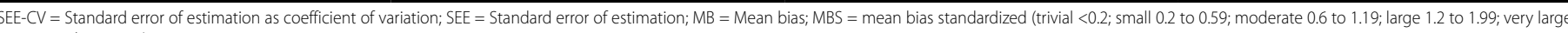
2.0 to 3.99 ; large $\geq 4.0$ )

\section{CONCLUSION}

The electrogoniometer can be used as a way to estimate different velocity parameters in the horizontal leg press exercise, especially for loads of 60 and $80 \%$ of 1 RM. The performance of the accelerometer was inferior to that of the potentiometer, with greater reliability to establish the average velocity and peak only for $80 \%$ of $1 \mathrm{RM}$. One limitation of the present study was the impossibility of comparing the values of velocities with gold standard.

All authors declare no potential conflict of interest related to this article

AUTHORS' CONTRIBUTIONS: Each author made significant individual contributions to this manuscript. AVSLL and ALDG: responsible for elaborating the research project, processing the data, statistical analysis, description of the results, discussion and critical review; ARSS, AGSN, CLL: performed the experimental procedures of data collection and processing, contributed to the intellectual concept, discussion of the results and critical review; SRM (0000-0002-3068-5093)*: contributed to the intellectual concept, discussion of the results and critical review. All the authors reviewed and approved the final version of the manuscript.

\section{REFERENCES}

1. American College of Sports Medicine. American College of Sports Medicine position stand. Progression models in resistance training for healthy adults. Med Sci Sports Exerc. 2009;41(3):687-708.

2. González-Badillo JJ, Sánchez-Medina L. Movement velocity as a measure of loading intensity in resistance training. Int J Sports Med. 2010;31(5):347-52.

3. Hackett DA, Davies TB, Orr R, Kuang K, Halaki M. Effect of movement velocity during resistance training on muscle-specific hypertrophy: A systematic review. Eur J Sport Sci. 2018;18(4):473-82.

4. Sakamoto A, Sinclair PJ. Muscle activations under varying lifting speeds and intensities during bench press. Eur J Appl Physiol. 2012;112(3):1015-25.

5. Murphy AJ, Wilson GJ. The assessment of human dynamic muscular function: a comparison of isoinertial and isokinetic tests. J Sports Med Phys Fitness. 1996;36(3):169-77.

6. Sánchez-Medina L, González-Badillo JJ. Velocity loss as an indicator of neuromuscular fatigue during resistance training. Med Sci Sports Exerc. 2011;43(9):1725-34

7. Sánchez-Medina L, Pallarés JG, Pérez CE, Morán-Navarro R, González-Badillo JJ. Estimation of relative load from bar velocity in the full back squat exercise. Sports Med Int Open. 2017;1(2):E80-8.

8. Conceição F, Fernandes J, Lewis M, Gonzaléz-Badillo JJ, Jimenéz-Reyes P. Movement velocity as a measure of exercise intensity in three lower limb exercises. J Sports Sci. 2016;34(12):1099-106.

9. García-Ramos A, Pestaña-Melero FL, Pérez-Castilla A, Rojas FJ, Haff GG. Differences in the Load-Velocity Profile Between 4 Bench-Press Variants. Int J Sports Physiol Perform. 2018;13(3):326-31.

10. Banyard HG, Nosaka K, Sato K, Haff GG. Validity of various methods for determining velocity, force, and power in the back squat. Int J Sports Physiol Perform. 2017;12(9):1170-6.
11. Comstock BA, Solomon-Hill G, Flanagan SD, Earp JE, Luk HY, Dobbins KA, et al. Validity of the Myotest ${ }^{\circ}$ in measuring force and power production in the squat and bench press. J Strength Cond Res. 2011;25(8):2293-7.

12. Orange ST, Metcalfe JW, Liefeith A, Marshall P, Madden LA, Fewster CR, et al. Validity and reliability of a wearable inertial sensor to measure velocity and power in the back squat and bench press. $J$ Strength Cond Res. 2019;33(9):2398-2408.

13. Balsalobre-Fernández C, Marchante D, Muñoz-López M, Jiménez SL. Validity and reliability of a novel iPhone app for the measurement of barbell velocity and 1RM on the bench-press exercise. J Sports Sci. 2018;36(1):64-70.

14. Jidovtseff B, Croisier JL, Lhermerout C, Serre L, Sac D, Crielaard JM. The concept of iso-inertial assessment: reproducibility analysis and descriptive data. Isokinet Exerc Sci. 2006;14(1):53-62.

15. Lorenzetti S, Lamparter T, Lüthy F. Validity and reliability of simple measurement device to assess the velocity of the barbell during squats. BMC Res Notes. 2017;10(1):707.

16. Thompson CJ, Bemben MG. Reliability and comparability of the accelerometer as a measure of muscular power. Med Sci Sports Exerc. 1999;31(6):897-902.

17. Hopkins WG. Spreadsheets for analysis of validity and reliability. Sportscience. 2015;19:36-42.

18. Balsalobre-Fernández C, Kuzdub M, Poveda-Ortiz P, Campo-Vecino JD. Validity and Reliability of the PUSH Wearable Device to Measure Movement Velocity During the Back Squat Exercise. J Strength Cond Res. 2016;30(7):1968-74.

19. Caruso JF, Olson NM, Taylor ST, McLagan JR, Shepherd CM, Borgsmiller JA, et al. Front squat data reproducibility collected with a triple-axis accelerometer. J Strength Cond Res. 2012;26(1):40-6. 